\title{
Public health investments: neglect or wilful omission? Historical trends in Quebec and implications for Canada
}

\author{
Julie Fiset-Laniel ${ }^{1} \cdot$ Ak'ingabe Guyon $^{1,2,3} \cdot$ Robert Perreault $^{3} \cdot$ Erin C. Strumpf ${ }^{1,4}$
}

Received: 28 January 2020 / Accepted: 12 May 2020 / Published online: 8 June 2020

(C) The Canadian Public Health Association 2020

\begin{abstract}
This commentary explores public health $(\mathrm{PH})$ investments in Quebec and underlines the challenge of tracking PH resources across Canada. We analyzed governmental data to compare investments across all health and social programs in Quebec from 2004-2005 to 2017-2018. The province's PH budgets suffered from disproportionately low investments and abrupt cuts. These cuts were the largest among all health programs in 2015-2016 (-7.1\%). PH budgets did not keep up with inflation and, in constant dollars, have declined over the last decade. Furthermore, their evolution over the span of 14 years significantly differed from other health programs. On average, programs providing direct services experienced overall budget increases of $81 \%$, whereas PH budgets had the lowest increase of all such programs at only $46 \%$. PH suffers from serious erosion of its capacity. Unfortunately, there is a dire lack of comparable data for provincial, national, and international PH budgets, which further complicates the monitoring of PH erosion. We contend that systematic tracking of PH budgets remains profoundly inadequate across Canada. We recommend (1) regular, comprehensive, and publicly reported analyses of PH budgets; (2) in-depth comparisons of PH investments across Canadian jurisdictions; and (3) a strong PH systems and services research agenda for Canada.
\end{abstract}

\section{Résumé}

Cet article explore les investissements en santé publique (SP) au Québec et souligne les défis inhérents au monitorage des ressources de SP au Canada. Nous avons analysé les données gouvernementales afin de comparer les investissements dans l'ensemble des programmes de santé et de services sociaux au Québec, de 2004-2005 à 2017-2018. Les budgets de SP au Québec ont souffert de façon disproportionnée d'investissements faibles et de coupes budgétaires abruptes. En 2015-2016, ces coupes ont été les plus importantes parmi celles imposées aux programmes de santé $(-7,1 \%)$. Les budgets de SP n'ont pas suivi l'inflation et, en dollars constants, ont décliné depuis environ dix ans. De plus, leur évolution durant les 14 dernières années diffère significativement de celle des autres programmes de santé. En moyenne, le budget des programmes qui fournissent des services directs a augmenté de $81 \%$, alors que l'augmentation des budgets de SP a été la plus faible parmi ces programmes, à $46 \%$. Pendant ce temps, la SP subit une érosion sévère de sa capacité. Malheureusement, il y a un manque criant de données comparables entre juridictions provinciales, nationales et internationales. Cette lacune vient compliquer toute tentative de documenter une telle érosion. Nous considérons que le suivi systématique des budgets de santé publique demeure profondément inadéquat au Canada. Nous recommandons (1) des analyses régulières, détaillées et publiques des budgets de SP; (2) des comparaisons en profondeur des investissements en SP au Canada; et (3) un programme de recherche canadien vigoureux en études des systèmes et services de SP.

Keywords Public health $\cdot$ Public health administration $\cdot$ Funding $\cdot$ Health expenditures $\cdot$ Canada $\cdot$ Quebec

Mots-clés Santé publique · Santé publique, administration · Financement · Dépenses en santé · Canada · Québec

Erin C. Strumpf

erin.strumpf@mcgill.ca

1 Department of Epidemiology, Biostatistics and Occupational Health, McGill University, 1020 Pine Ave West, Montreal, QC H3A 1A2, Canada
2 School of Public Health, Université de Montréal, 7101, avenue du Parc, 3e étage, Montreal, QC H3N 1X9, Canada

3 Direction régionale de santé publique, 1301 Sherbrooke St E, Montreal, QC H2L 1M3, Canada

4 Department of Economics, McGill University, 855 Sherbrooke Street West, Montreal, QC H3A 2T7, Canada 


\section{Public health investments: insufficient analyses}

The current COVID-19 pandemic has brought public health to the forefront of public attention and imagination. Citizens around the globe are more aware than ever of the diverse and important roles that public health plays, from surveillance to communication with the public to the coordination of health policies and resources. Our public health directors and handwashing experts are internet stars. This spotlight has brought with it questions about the adequacy of our investments in population health, of public health budgets, and of public health preparedness.

Health system experts have long recognized that public health $(\mathrm{PH})$ functions are fundamental pillars of viable health systems and better population health (Thompson et al. 2014; Gmeinder et al. 2017). Yet, the scarce resources allocated to PH contradict policy-makers' endorsement of prevention imperatives (Gmeinder et al. 2017; Guyon et al. 2017) and are at odds with the substantial health impacts of $\mathrm{PH}$ investments (Singh 2014). The consequences of limited investments have become all too clear recently, as questions about whether we could have been better prepared have multiplied (Tunney 2020). Surprisingly, and despite repeated calls for appropriate budget monitoring and adequate investments, there are very few Canadian or international systematic analyses of PH funding (Leider 2016; Guyon et al. 2017; Rechel et al. 2018).

This commentary sheds some light on one province's PH investments. We analyzed health program budgets in Quebec since 2004 and compared investments in PH with those elsewhere in the health system. We conclude that PH continues to suffer from a disproportionate and significant erosion of its capacity to enhance and protect population health (Guyon et al. 2017; Hancock 2018). Moreover, our analysis and the conclusions of national and international reports underscore that, 15 years after the National Advisory Committee on SARS and Public Health (2003), systematic tracking of PH budgets remains profoundly inadequate.

\section{PH funding in Quebec: disproportionately low investments and abrupt cuts}

Quebec was once considered the province with the most comprehensive PH system (Canadian Institutes of Health Research 2003). In 2015, the provincial government abruptly imposed 33\% budget cuts on the regional PH teams (Guyon and Perreault 2016). That same year, the long-standing threetiered PH system was also restructured into two tiers: local PH teams were placed under the functional authority of regional $\mathrm{PH}$ units, while the ministerial tier was maintained.

In order to contextualize these cuts within health services funding, we analyzed publicly available data from the Ministry of Health and Social Services (MHSS) budgetary dataset from financial years 2004-2005 to 20172018 (Ministère de la Santé et des Services sociaux 2019). Since 2004, MHSS structures its service and accounting system through 12 programs: 9 service delivery programs and 3 administrative and logistical support programs (Ministère de la Santé et des Services sociaux 2004). PH is one of the 9 programs that deliver direct services to the population. The MHSS dataset provides $\mathrm{PH}$ budgets for provincially funded $\mathrm{PH}$ services delivered by regional $\mathrm{PH}$ units and local health centres. This funding covers $\mathrm{PH}$ interventions such as health surveillance, health promotion, and clinical preventive measures (e.g., immunization, early childhood development services, prevention of sexually transmitted infections), and health protection interventions (Litvak et al. 2019). The MHSS dataset excludes governmental funding of the following: the office of the Chief Medical Officer of Health; the provincial PH institute Institut National de Santé Publique (INSPQ); PH professionals remunerated by the provincial insurer Régie de l'Assurance Maladie du Québec (RAMQ); occupational health interventions funded by the provincial workers compensation board; and major portions of the budgets of nongovernmental organizations providing $\mathrm{PH}$ services.

Between 2004-2005 and 2017-2018, programs providing direct health and social services experienced overall budget increases of $81 \%$ (Table 1; Fig. 1). However, PH displayed a contrasting trend: it had by far the lowest budget increase of all service delivery programs at only $46 \%$. Furthermore, between 2004-2005 and 2017-2018, annual budget increases for all programs averaged $4.2 \%$, whereas annual budget increases for $\mathrm{PH}$ averaged $3.1 \%$, the lowest of all service delivery programs.

The fiscal year 2015-2016 was unusual, with the lowest average annual budget increase for all health programs, at only $1.0 \%$ (Table 1; Fig. 2). That year, substantial cuts were imposed upon several health programs, and particularly on $\mathrm{PH}$ : $-\$ 23.5$ million which corresponded to $-7.1 \%$. These cuts of $\$ 23.5$ million were entirely directed at regional $\mathrm{PH}$ units, whose total budget that year was $\$ 72$ million. This resulted in 33\% cuts to regional PH teams' budgets (Daoust-Boivert 2015; Guyon and Perreault 2016). That same year, only four other programs experienced cuts: three programs providing direct services were cut by less than $-0.9 \%$ (developmental disorders, addictions, physical disability) and one administrative program was cut by $-2.4 \%$ (support to services). Meanwhile, four programs providing direct services benefited from increased funding, though generally less than in previous years (support for seniors $+1.2 \%$, physical health $+1.6 \%$, youth in difficulty $2.2 \%$, general services $+5.6 \%$ ). Furthermore, two of the three administrative programs were granted budget increases (building management $+0.6 \%$, administration $+2.7 \%$ ) . 
Table 1 Evolution of budgets for all health and socially oriented health services programs in Quebec, 2004-2005 to 2017-2018

\begin{tabular}{|c|c|c|c|c|c|c|}
\hline & Programs & $\begin{array}{l}\text { Share of total } \\
\text { budget (2017-2018) }\end{array}$ & $\begin{array}{l}2017-2018 \\
\text { (current, \$) }\end{array}$ & $\begin{array}{l}\% \text { change } \\
\text { between } 2004-2005 \\
\text { and 2017-2018 }\end{array}$ & $\begin{array}{l}\text { Average annual } \\
\text { budget increase } \\
\text { between 2004-2005 } \\
\text { and 2017-2018 }\end{array}$ & $\begin{array}{l}\% \text { change } \\
\text { between 2014-2015 } \\
\text { and 2015-2016 }\end{array}$ \\
\hline \multirow[t]{10}{*}{ Services } & Physical health & $37.0 \%$ & 8.5 billion $\$$ & $+88 \%$ & $+5.0 \%$ & $+1.6 \%$ \\
\hline & Support for seniors & $16.1 \%$ & 3.7 billion $\$$ & $+82 \%$ & $+4.7 \%$ & $+1.2 \%$ \\
\hline & Mental health & $5.9 \%$ & 1.4 billion $\$$ & $+66 \%$ & $+4.0 \%$ & $+0.1 \%$ \\
\hline & Youth in difficulty & $5.7 \%$ & 1.3 billion $\$$ & $+60 \%$ & $+3.7 \%$ & $+2.2 \%$ \\
\hline & Developmental disorders & $4.6 \%$ & 1.0 billion $\$$ & $+77 \%$ & $+4.6 \%$ & $-0.4 \%$ \\
\hline & General services & $4.2 \%$ & 953 million $\$$ & $+101 \%$ & $+5.6 \%$ & $+5.6 \%$ \\
\hline & Physical disability & $2.9 \%$ & 661 million \$ & $+80 \%$ & $+4.6 \%$ & $-0.9 \%$ \\
\hline & Public health & $1.4 \%$ & 324 million \$ & $+46 \%$ & $+3.1 \%$ & $-7.1 \%$ \\
\hline & Addictions & $0.5 \%$ & 126 million \$ & $+76 \%$ & $+4.5 \%$ & $-0.9 \%$ \\
\hline & All service programs & & & $+81 \%$ & $+4.4 \%$ & $+1.2 \%$ \\
\hline \multirow[t]{4}{*}{ Administration } & Building management & $7.7 \%$ & 1.8 billion $\$$ & $+43 \%$ & $+2.8 \%$ & $+0.6 \%$ \\
\hline & Support to services & $7.4 \%$ & 1.7 billion $\$$ & $+41 \%$ & $+2.8 \%{ }^{\mathrm{a}}$ & $-2.4 \%$ \\
\hline & Administration & $6.5 \%$ & 1.5 billion $\$$ & $+42 \%$ & $+3.2 \%$ & $+2.7 \%$ \\
\hline & All support programs & & & $+42 \%$ & $+3.0 \%$ & $+0.1 \%$ \\
\hline Total & & $100 \%$ & 22.9 billion $\$$ & $+71 \%$ & $+4.2 \%$ & $+1.0 \%$ \\
\hline
\end{tabular}

In the MHSS 2012-2013 dataset, the support to services program budget is recorded as 0 \$; hence, it was not possible to calculate annual budget increases for 2012-2013 and 2013-2014. We excluded those two fiscal years in order to calculate the average annual budget increase for this program between 2004-2005 and 2017-2018

These findings are entirely incompatible with the justifications provided by the Quebec government in 2015, indicating that the abrupt $\mathrm{PH}$ cuts were administrative cutbacks in times of generalized budgetary constraints (Guyon and Perreault 2016). In fact, the generalized budgetary constraints were strikingly selective and disproportionately directed to

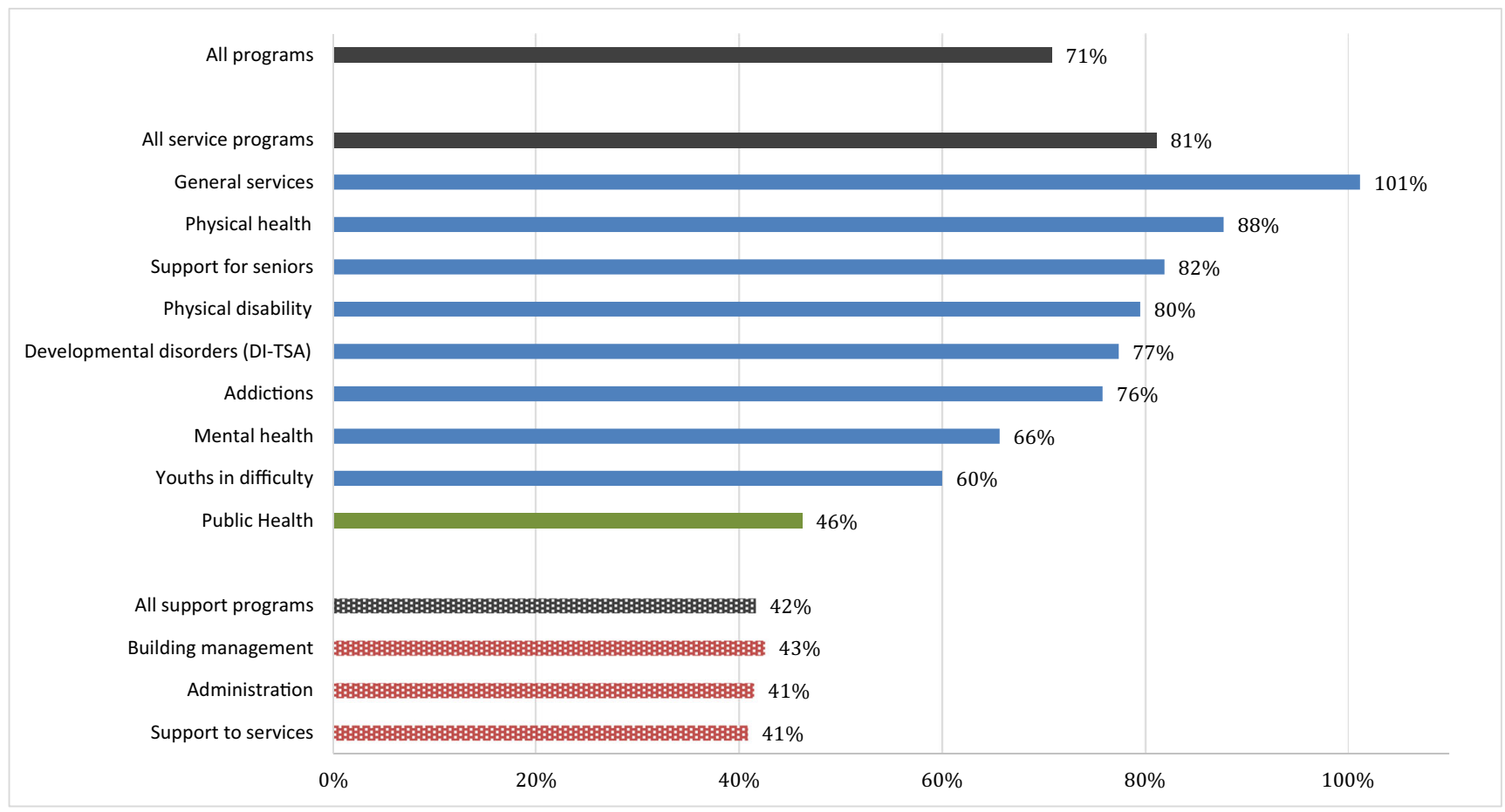

Fig. 1 Percentage change in budgets of health and socially oriented health services programs in Quebec between 2004-2005 and 2017-2018 (current dollars) 


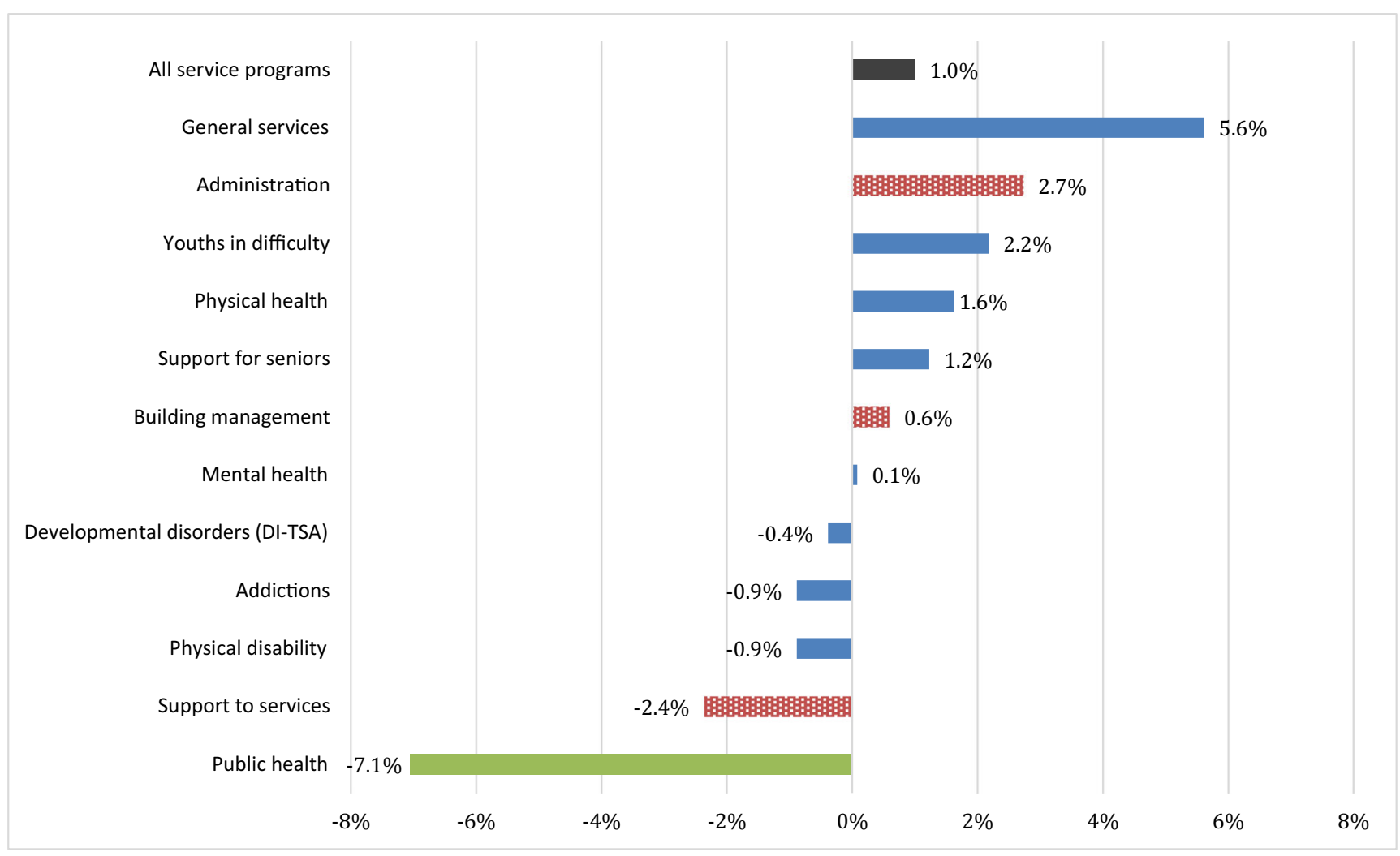

Fig. 2 Percentage change in budgets among health and socially oriented health services programs in Quebec between 2014-2015 and 2015-2016 in current dollars

regional $\mathrm{PH}$ services. Cuts to the $\mathrm{PH}$ budget, a service delivery program, of $7.1 \%$ were nearly three times as large as the next largest cut, to the administrative support to services program at $2.4 \%$.

We also analyzed trends in public health investments relative to inflation, in current dollars and constant 2002 dollars using Statistics Canada's Consumer Price Index (data not shown). After accounting for inflation, $\mathrm{PH}$ budgets increased by only 17\% between 2004-2005 and 2017-2018. In 2002 constant dollars, public health budgets were higher in 2008-2009 than they were a decade later (\$257 million vs. \$250 million). Yet, since the 2015-2016 cuts, PH has had the lowest budget increase at $4.5 \%$, whereas the average budget increase for all health programs was at $8.1 \%$ (in current dollars).

In summary, from 2004-2005 to 2017-2018, PH budgets in Quebec suffered from disproportionately low investments and abrupt cuts. These cuts were the largest among all health programs in 2015-2016 (-7.1\%). PH budgets did not keep up with inflation and, in constant dollars, have declined over the last decade. Furthermore, their evolution over the span of 14 financial years (2004-2018) significantly differed from other health programs. Programs providing direct health and social services experienced overall budget increases of $81 \%$, whereas $\mathrm{PH}$ had the lowest increase among such programs at only $46 \%$.

\section{Estimating PH funding: data limitations}

Data on PH investments suffer from well-documented limitations (Leider 2016; Gmeinder et al. 2017; Guyon et al. 2017; Rechel et al. 2018) that also apply to the dataset we studied. First, publicly available statements of accounts (Rapports financiers annuels des établissements) do not allow a clear identification of what specific services and infrastructure costs are included in the reported budgets. Second, $\mathrm{PH}$ financial data are particularly prone to misclassifications or incomplete reporting of expenditures, given the breadth and heterogeneity of the PH field and its imprecise borders with primary health care. Third, the MHSS budgetary dataset is not a comprehensive portrait of all PH investments in Quebec. It excludes major components of Quebec's PH investments made by the INSPQ, RAMQ, the provincial workers compensation board, and by publicly funded NGO services. Consequently, it is difficult to accurately compare $\mathrm{PH}$ budgets between different Canadian and international jurisdictions (Gmeinder et al. 2017; Guyon et al. 2017). The lack of clear and comparable data on PH spending limits our ability to evaluate the impacts of investments, disinvestments, and policy changes, and to learn from different approaches across jurisdictions.

In order to better understand $\mathrm{PH}$ investments in Canada, we recommend several strategies. First, provinces and territories 
should mandate independent institutions to conduct regular, comprehensive, and publicly reported analyses of PH budgets. So far, this mandate is only fulfilled intermittently, for instance by auditors general. Second, federally funded panCanadian health organizations such as the Canadian Institute for Health Information (CIHI) should intensify their efforts to reliably document PH investments across Canada. Even if such analyses are currently complex, they can help document what constitutes $\mathrm{PH}$ in different jurisdictions and support the tracking and assessment of $\mathrm{PH}$ investment. Third, $\mathrm{PH}$ infrastructure, which includes investments and workforce, should constitute a steady research focus for Canadian PH systems and services researchers, and this should be unequivocally supported by research granting agencies.

\section{Tracking and beyond: considerable room for increased investments}

Disproportionately low $\mathrm{PH}$ funding is unfortunately not an isolated phenomenon among Canadian provinces nor OECD countries, pointing to considerable room for increased investments (Gmeinder et al. 2017; Rechel et al. 2018). PH cuts are almost unanimously condemned as political decisions that fly in the face of logic. As summarized in a recent WHO Europe policy paper: "cuts to $\mathrm{PH}$ budgets may help countries to meet short-term cost containment goals but are likely to lead to cost increases and lower population health gains in the longer term" (Thompson et al. 2014). As countries around the world are facing a public health and economic crisis unprecedented in living memory, those birds are coming home to roost.

While our analysis focused on the gap between investments in public health and other categories of health care spending, we recognize that investments in the social determinants of health also contribute to population health outcomes and our ability to mitigate the impacts of public health crises. In Canada and the United States, COVID-19 is disproportionately harming vulnerable populations: visible minorities, the homeless, and individuals in seniors' residences (USCDC 2020; Bartholomew 2020; Pedersen and Mancini 2020). The interventions of shutting down economies and physically isolating ourselves are proving effective at limiting the spread of the virus, but are also putting immense strains on our childcare, education, and employment insurance systems.

The disproportionately low public health investments that we document here mirror relatively low investments in social determinants of health relative to health spending (Kershaw 2020; Tran et al. 2017). Municipal and state/provincial governments are often primarily responsible for spending on both public health and social determinants of health. Unlike their federal counterparts, many are not legally permitted to run budget deficits, which further constrains their capacities to make these investments, particularly during economic downturns. More attention to, and adequate investment in, both public health and social determinants of health are needed to protect population health during epidemics and beyond.

Mechanisms to safeguard PH funding do exist and include increased accountability, protected budgets, and the setting of funding targets (Gmeinder et al. 2017). Proposed targets for governmental $\mathrm{PH}$ funding in Canada are $5 \%$ to $6 \%$ of the total governmental health system expenditure (Advisory Committee on Population Health and Health Security 2005). While the MHSS dataset is focused on health programs funding, CIHI generates a more comprehensive although imprecise portrait of total PH budgets across Canada. According to CIHI estimates, $\mathrm{PH}$ in Quebec receives the lowest proportion of total health expenditures $(2.2 \%)$ across all provinces and territories, and compared with the Canadian average $(5.4 \%)$ (Canadian Institute for Health Information 2019).

Better tracking of $\mathrm{PH}$ budgets needs to become a priority in order to secure and expand PH's capacity to improve population health and health equity. Transparent data across federal, provincial, and territorial jurisdictions are needed to track public health investments over time, to compare them across jurisdictions, and to understand their impacts. Most importantly, better tracking allows citizens and $\mathrm{PH}$ advocates to hold governments accountable for their wise or harmful budgetary decisions.

\section{Compliance with ethical standards}

Conflict of interest The authors declare that they have no conflict of interest.

\section{References}

Advisory Committee on Population Health and Health Security. (2005). Improving public health system infrastructure. Public Health Agency of Canada https://books.google.ca/books/about/ Improving_Public_Health_System_Infrastru.html?id= JxH5jwEACAAJ\&redir_esc $=y$.

Bartholomew, A. (2020). Why housing the homeless in the age of Covid19 is essential. Forbes.com, April 3. https://www.forbes.com/sites/ anitabartholomew/2020/04/03/why-housing-the-homeless-in-theage-of-covid-19-is-essential/\#13d6a6583284

Canadian Institute for Health Information. (2019). National Health Expenditure Database (NHEX). Data tables: Health spending. Data tables: health spending (Series D1-2019-En) https://www. cihi.ca/en/national-health-expenditure-trends-1975-to-2019

Canadian Institutes of Health Research. (2003). The future of public health in Canada: Developing a public health system for the 21st century. http://neltoolkit.rnao.ca/sites/default/files/Future_of Public_Health in_Canada_2003.pdf

Daoust-Boivert, A. (2015) Coupes majeures en régions, Le Devoir, March 2. https://www.ledevoir.com/societe/sante/433265/santepublique-coupes-majeures-en-regions

Gmeinder, M.D., Morgan, D., \& Mueller, M. (2017). How much do OECD countries spend on prevention ? OECD Health working papers no. 101. OECD Publishing, Paris. https://doi.org/10.1787/ f19e803c-en 
Guyon, A., \& Perreault, R. (2016). Public health systems under attack in Canada: Evidence on public health system performance challenges arbitrary reform. Can J Public Health. https://doi.org/10.17269/ cjph.107.5273.

Guyon, A., Hancock, T., Kirk, M., MacDonald, M., Neudorf, C., Sutcliffe, P., Talbot, J., \& Watson-Creed, G. (2017). The weakening of public health: A threat to population health and health care system sustainability. Can J Public Health, 108(1), e1-e6. https://doi.org/ 10.17269/CJPH.108.6143.

Hancock, T. (2018). Erosion of public health capacity should be a matter of concern for all Canadians. Can J Public Health, 108(5-6), E458E461. https://doi.org/10.17269/cjph.108.6556.

Kershaw, P. (2020). A 'health in all policies' review of Canadian public finance. Can J Public Health. https://doi.org/10.17269/s41997-01900291-4.

Leider, J. P. (2016). The problem with estimating public health spending. J Public Health Manag Pract, 22(2), E1-E11. https://doi.org/10. 1097/PHH.0b013e3182941a7b.

Litvak, E., Dufour, R., Leblanc, É., Kaiser, D., Mercure, S. A., Nguyen, C. T., \& Thibeault, L. (2019). Making sense of what exactly public health does: A typology of public health interventions. Can J Public Health. https://doi.org/10.17269/s41997-019-00268-3.

Ministère de la Santé et des Services sociaux. (2004). L'architecture des services de santé et des services sociaux. Les programmes-services et les programmes-soutien. https://publications.msss.gouv.qc.ca/ msss/fichiers/2004/04-710-01.pdf

Ministère de la Santé et des Services sociaux. (2019). Contour financier, statistiques et données. https://publications.msss.gouv.qc.ca/msss/ document-001663/

National Advisory Committee on SARS and Public Health. (2003). Learning from SARS: Renewal of public health in Canada. Ottawa: Health Canada http://www.phac-aspc.gc.ca/publicat/sarssras/naylor/index-eng.php.

Pedersen, K., Mancini, M. (2020). 'Spreads like wildfire': More than half of COVID-19 deaths in Canada have been seniors' home residents.
CBC News, March 25. https://www.cbc.ca/news/health/covid-19nursing-home-elderly-1.5509915

Rechel, B., Jakubowski, E., McKee, M., \& Nolte, E. (2018). Organization and financing of public health services in Europe. WHO Europe, European Observatory on Health Systems and policies. Health Policy Series 50. http://www.euro.who.int/_data/ assets/pdf_file/0009/383544/hp-series-50-eng.pdf?ua=1

Singh, S. R. (2014). Public health spending and population health: A systematic review. Am J Prev Med, 47(5), 632-640. https://doi. org/10.1016/j.amepre.2014.05.017.

Thompson, S., Figueras, J., Evetovits, T., Jowett, M., Mdladovsky, P., Maresso, A., Cylus, J., Karanikolos, M., \& Kluge, H. (2014). Economic crisis, health systems and health in Europe: Impact and implications for policy. Policy summary. World Health Organization, Regional Office for Europe. European Observatory on Health Systems and Policies. http://www.euro.who.int/_data/ assets/pdf_file/0008/257579/Economic-crisis-health-systemsEurope-impact-implications-policy.pdf

Tran, L. D., Zimmerman, F. J., \& Fielding, J. E. (2017). Public health and the economy could be served by reallocating medical expenditures to social programs. SSM - Population Health, 3, 185-191.

Tunney, C. (2020). Ottawa 'likely did not have enough' protective gear stockpiled: Hajdu. CBC News, April 1. https://www.cbc.ca/news/ politics/hajdu-stockpile-coronavirus-covid-pandemic-1.5517321

United States Centers for Disease Control. (2020). Hospitalization rates and characteristics of patients hospitalized with laboratoryconfirmed coronavirus disease 2019 - COVID-NET, 14 states, March 1-30, 2020. https://www.cdc.gov/mmwr/volumes/69/wr/ $\mathrm{mm} 6915 \mathrm{e} 3 . \mathrm{htm}$

Publisher's note Springer Nature remains neutral with regard to jurisdictional claims in published maps and institutional affiliations. 